\title{
Correlations between components of the water balance and burned area reveal new insights for predicting forest fire area in the southwest United States
}

\author{
A. Park Williams ${ }^{\mathrm{A}, \mathrm{I}}$, Richard Seager ${ }^{\mathrm{A}}$, Alison K. Macalady ${ }^{\mathrm{B}}$, \\ Max Berkelhammer', Michael A. Crimmins ${ }^{\mathrm{C}}$, Thomas W. Swetnam ${ }^{\mathrm{B}}$, \\ Anna T. Trugman ${ }^{\mathrm{E}}$, Nikolaus Buenning ${ }^{\mathrm{F}}$, David Noone ${ }^{\mathrm{C}}$, Nate G. McDowell ${ }^{\mathrm{G}}$, \\ Natalia Hryniw ${ }^{\mathrm{H}}$, Claudia I. Mora ${ }^{\mathrm{G}}$ and Thom Rahn ${ }^{\mathrm{G}}$ \\ A Lamont-Doherty Earth Observatory of Columbia University, Palisades, NY 10964, USA. \\ ${ }^{B}$ Laboratory of Tree-Ring Research, University of Arizona, Tucson, AZ 85724, USA. \\ ${ }^{C}$ Department of Atmospheric \& Oceanic Sciences, Cooperative Institute for Research in \\ Environmental Sciences, University of Colorado, Boulder, CO 80309, USA. \\ D Department of Soil, Water, and Environmental Science, University of Arizona, Tucson, \\ AZ 85721, USA. \\ E Department of Atmospheric \& Oceanic Sciences, Princeton University, Princeton, \\ NJ 08544, USA. \\ F Department of Earth Sciences, University of Southern California, Los Angeles, CA 90089, USA.

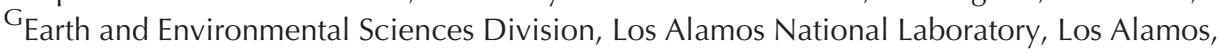 \\ NM 87545, USA. \\ ${ }^{H}$ Department of Atmospheric Sciences, University of Washington, Seattle, WA 98195, USA. \\ 'Corresponding author. Email: williams@Ideo.columbia.edu
}

\begin{abstract}
We related measurements of annual burned area in the southwest United States during 1984-2013 to records of climate variability. Within forests, annual burned area correlated at least as strongly with spring-summer vapour pressure deficit (VPD) as with 14 other drought-related metrics, including more complex metrics that explicitly represent fuel moisture. Particularly strong correlations with VPD arise partly because this term dictates the atmospheric moisture demand. Additionally, VPD responds to moisture supply, which is difficult to measure and model regionally due to complex micrometeorology, land cover and terrain. Thus, VPD appears to be a simple and holistic indicator of regional water balance. Coupled with the well-known positive influence of prior-year cold season precipitation on fuel availability and connectivity, VPD may be utilised for burned area forecasts and also to infer future trends, though these are subject to other complicating factors such as land cover change and management. Assuming an aggressive greenhouse gas emissions scenario, climate models predict mean spring-summer VPD will exceed the highest recorded values in the southwest in nearly $40 \%$ of years by the middle of this century. These results forewarn of continued increases in burned forest area in the southwest United States, and likely elsewhere, when fuels are not limiting.
\end{abstract}

Additional keywords: fire danger, tree mortality, warming.

Received 21 February 2014, accepted 28 August 2014, published online 13 November 2014

\section{Introduction}

Wildfire in the southwestern United States (SW) is influenced by drought on inter-annual to centennial timescales (Swetnam and Betancourt 1990, 1998; Grissino Mayer and Swetnam 2000; Trouet et al. 2006; Westerling et al. 2006; Littell et al. 2009; Marlon et al. 2009; Williams et al. 2013), and it is well known that drought increases the risk of wildfire by drying organic fuel sources (e.g. Byram and Jemison 1943; Keetch and Byram 1968;
Rothermel 1983; Nelson Jr. 2001; Benson et al. 2009). (We define the SW as Arizona and New Mexico, as well as areas of Texas, Oklahoma, Colorado and Utah that lie south of $38.0^{\circ} \mathrm{N}$, north of $28.5^{\circ} \mathrm{N}$ and west of $100.0^{\circ} \mathrm{W}$ (Fig. $1 a$, as in Williams et al. in press).) However, extreme spatial heterogeneity of landscape and fuel type in the western United States has prompted repeated efforts to develop reliable and mechanistic empirical connections between climate variability and wildfire 

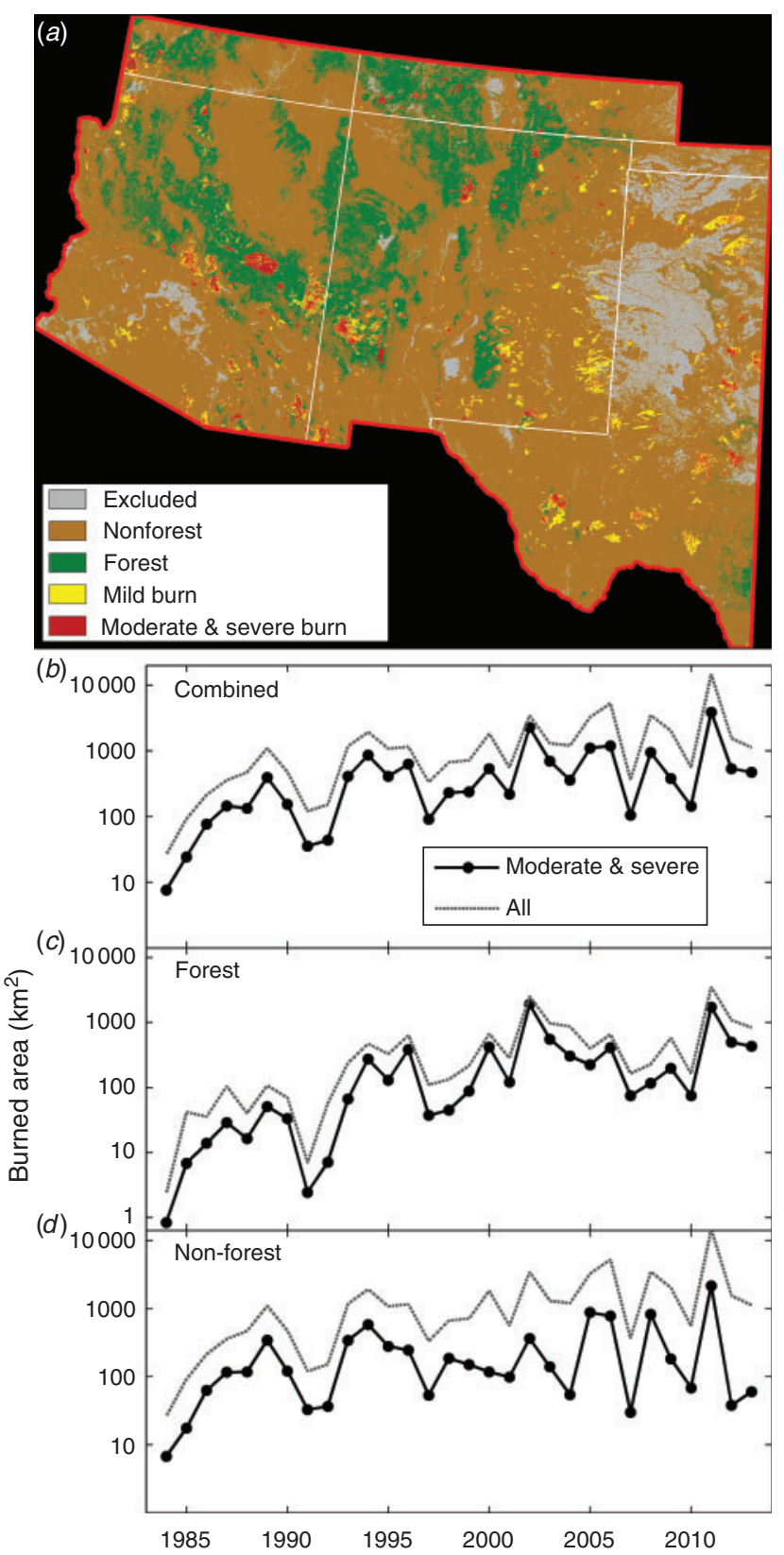

Fig. 1. Southwest (SW) wildfire area during 1984-2013. Map of the SW (a) shows areas burned mildly (yellow areas), and moderately or severely (red areas). Panels $(b-d)$ show time series of annual moderate and severe burned area in the entire SW $(b)$, forest area $(c)$ and non-forest area $(d)$. Grey time series in $(b-d)$ include mild burned areas. Burned area values on the $y$-axes increase on a $\log _{10}$ scale. Burned area for 2013 derived from MODIS data.

activity that bypass the need for complex fuel moisture modelling (e.g. Price and Rind 1994; Crimmin and Comrie 2004; Holden et al. 2007; Holden et al. 2009; Littell et al. 2009; Dillon et al. 2011; Abatzoglou and Kolden 2013; Riley et al. 2013). Consistent and highly correlated influences of climate variability on forest fire activity have been elusive in part because historic wildfire data are limited in terms of geographic representation, spatial resolution, temporal depth and ecological effects (Littell et al. 2009).

Littell et al. (2009) conducted one of the most thorough examinations of the climatic drivers of burned area in the western United States to date. Burned area in SW ecoprovinces for 1916-2003 was found to be associated primarily with fuel availability, dictated by prior-year precipitation and only secondarily related to drying of fuels during the year of fire. This conclusion was consistent with past findings (e.g. Westerling et al. 2002; Westerling et al. 2003; Crimmin and Comrie 2004), but these studies utilised spatially coarse burned area data and did not distinguish among land cover types, burn severities or elevations.

The problem of limited geographic detail in wildfire data is waning for the United States, as there are now nearly three decades of high-resolution, satellite-derived observations of burned area and burn severity developed through the Monitoring Trends in Burn Severity (MTBS) programme (Eidenshink et al. 2007). Riley et al. (2013) used MTBS data from 1984-2008 to demonstrate that locations and sizes of wildfires in the western United States correspond well with an estimate of flammability calculated from meteorological data. Abatzoglou and Kolden (2013) utilised MTBS data to develop annual records of forest and non-forest burned area for 1984-2010 within each of eight regions in the western United States. This study showed that among several drought-related climatological and biophysical variables, forest burned area in the SW correlated most strongly with potential evapotranspiration (PET). Williams et al. (2013) also utilised MTBS data to show that annual forest area burned in the SW corresponds strongly with a tree ring-based estimate of regional forest drought stress. Both Abatzoglou and Kolden (2013) and Williams et al. (2013) indicate that SW forest fire area may be more strongly influenced by current-year drought than was formerly recognised (e.g. Westerling et al. 2006; Littell et al. 2009).

An implication of observed drought-wildfire relationships in the SW is that warming may cause increased regional wildfire (e.g. Westerling et al. 2006; Fleishman et al. 2013), at least in the near term when fuels are not limiting. Warmth contributes to the drying of soils and fuels, enhancing forest flammability (Schoennagel et al. 2004; Westerling et al. 2006; Pechony and Shindell 2010), and can promote the creation of additional dead fuels through drought-induced tree mortality (e.g. Adams et al. 2009; Williams et al. 2013). Additionally, drought-stressed trees appear to be at increased risk of fire-induced tree mortality (van Mantgem et al. 2013), influencing post-fire fuel characteristics and possibly future fire activity (although the relationship between fuel characteristics and fire dynamics is complex; e.g. Linn et al. 2013).

Temperature is often used as a proxy for atmospheric moisture demand, although this quantity is more accurately represented by the vapour pressure deficit (VPD). VPD is defined as the saturation vapour pressure $\left(e_{s}\right)$ minus the actual vapour pressure $(e)$. Increasing temperature causes $e_{s}$ to increase exponentially, and this exponential relationship translates to an exponential influence of warming on VPD, even if $e$ increases such that relative humidity $(\mathrm{RH})$ remains constant (Anderson 1936). Although various measures of atmospheric moisture 
demand have been used in fire behaviour modelling (e.g. Werth et al. 2011), and various drought indices have been used to assess seasonal and longer-term associations with area burned, VPD has received relatively little attention as a potentially dominant indicator of wildfire vulnerability. An exception is a recent study indicating that wildfire spread in Alaskan boreal forests is strongly influenced by VPD during the days leading up to ignition (Sedano and Randerson 2014).

Here, we utilise 30 years (1984-2013) of satellite observations to quantify recent trends and inter-annual variability in burned area in the SW. We then evaluate relationships between SW wildfire and climate, building upon the previous results of Williams et al. (2013) and other recent investigations (e.g. Littell et al. 2009; Abatzoglou and Kolden 2013; Riley et al. 2013). We evaluate correlations between annual burned area in the SW (distinguishing between forest and non-forest) and 15 seasonal climate metrics, including VPD and several bioclimatic variables used in previous evaluations of climatewildfire relationships. We test the hypothesis that annual burned forest area is as strongly correlated with spring-summer VPD as it is with other drought-related metrics more commonly used to evaluate wildfire vulnerability. We also evaluate relationships between burned area and antecedent moisture conditions, distinguishing between forest and non-forest, and also, for the first time, among elevation classes within forests. Our findings provide new insights regarding the nature and strength of the relationships between SW wildfire and climate, with implications for seasonal burned area forecasting and future climateinduced wildfire trends. Observed wildfire-climate relationships in the already warm and dry SW may provide valuable insight relevant to other regions where climate is likely to become substantially warmer and drier.

\section{Data and methods}

\section{Annual burned area}

We calculated annual SW burned area using satellite data from 1984 to 2013 (see Fig. 1a for SW boundaries). For 1984-2012, we accessed data on wildfires larger than 404 ha from the United States Forest Service MTBS project (Eidenshink et al. 2007). MTBS classifies burn severities as low, moderate or severe based on measurements made by the Landsat satellite (30-m geographic resolution. As in Williams et al. (2010, 2013), we excluded low severities because severities are classified based on likelihood of ecological change (Eidenshink et al. 2007) and we were most concerned with identifying climate-fire relationships that influence vegetation mortality or damage. We updated burned area records through 2013 using the burned area product derived from Moderate Resolution Imaging Spectroradiometer (MODIS) satellite imagery (version 5.1) (Roy et al. 2008). Although MODIS only provides one additional year of data, it allows for our estimates of total area burned and associated trends to be as up to date as possible. See S1 and Fig. S1 as Supplementary Material to this paper for methods used to estimate burned area from MODIS. We distinguished between forest and non-forest burned area using the 1992 National Land Cover Dataset (NLCD). Forest land cover is classified as 'conifer' or 'mixed' (as in Method \#4 of Williams et al. 2010). Within SW forest, we calculated sub-regional burned area records within various elevation bands using the United States Geological Survey digital elevation model dataset. We excluded non-natural and non-vegetated areas (e.g. city, farmland, sand dunes, water).

\section{Observed climate data}

We evaluated surface climate variables using gridded monthly data from the PRISM group at Oregon State University (Daly et al. 2004; PRISM Climate Group, Oregon State University, www.prism.oregonstate.edu). Geographic resolution is $\sim 4 \mathrm{~km}$, temporal coverage used here is 1961-2013, and variables are precipitation, maximum daily temperature $\left(T_{\max }\right)$, minimum daily temperature $\left(\mathrm{T}_{\min }\right)$ and dew point. Although other climate datasets are available, PRISM is preferred when possible because of its higher spatial resolution and inclusion of station data from the Remote Automated Weather Station (RAWS) network, which is partly intended for fire danger evaluation. See Supplementary Material S2 for a comparison of PRISM to alternative datasets. We calculated monthly VPD using methods described in Supplementary Material S3.

For variables not available via PRISM, we used the monthly and hourly dataset developed for Phase 2 of the North American Land Data Assimilation System (NLDAS-2) (Mitchell et al. 2004) for 1979-2013. These variables were PET, water deficit (PET minus actual evapotranspiration), insolation (downward solar radiation at the surface), wind speed and soil moisture in the top $10 \mathrm{~cm}$. Among these, water deficit and soil moisture were calculated by the Noah land surface model, forced with NLDAS-2 meteorological data (Xia et al. 2012). NLDAS-2 and Noah data (http://ldas.gsfc.nasa.gov/nldas) are described in Supplementary Material S4.

In addition to standard climate variables, we evaluated four drought indices commonly used to monitor drought and wildfire risk: Palmer Drought Severity Index (PDSI; Palmer 1965), Keetch-Byram Drought Index (KBDI; Keetch and Byram 1968), Standardised Precipitation-Evaporation Index (SPEI; Vicente-Serrano et al. 2010), and Energy Release Component (ERC; Abatzoglou 2013). ERC is an estimate of energy flux from the flaming front of a head fire (Fujioka et al. 2009), shown by Riley et al. (2013) and Abatzoglou and Kolden (2013) to correspond strongly with wildfire area and occurrence throughout the western United States. The KBDI and ERC are used for tactical planning within the United States Forest Service National Fire Danger Rating System (Fujioka et al. 2009). Table 1 provides more information about these four indices.

\section{Correlation analysis of climate versus burned area}

We tested correlations between annual burned area and 15 climate variables (listed in Table 2). As in Littell et al. (2009), burned area was $\log _{10}$ transformed to account for the exponential distribution of annual burned area. Also like Littell et al. (2009), we removed first-order autocorrelation from all burned area and climate time series to satisfy assumptions of sample independence before correlation analysis. This helps assure that correlations between burned area and climate are due to interannual co-variability, independent of common decadal trends that may not necessarily be mechanistically related. For each variable, we identified the range of 3-6 months during the 
Table 1. Drought indices considered

\begin{tabular}{|c|c|c|c|c|c|}
\hline Variable & Variable simulated & Source & Years & Spatial resolution & Notes \\
\hline $\begin{array}{l}\text { PDSI: Palmer Drought Severity } \\
\text { Index }\end{array}$ & Soil moisture & $\begin{array}{l}\text { A } \\
\text { B }\end{array}$ & $\begin{array}{l}1948-2008 \\
1895-2013\end{array}$ & $\begin{array}{l}1^{\circ} \text { interpolated to } 1 / 8^{\circ} \\
\text { Climate division averages } \\
\text { gridded to } 1 / 8^{\circ}\end{array}$ & $\begin{array}{l}\text { (A) extended through } 2013 \text { using (B), } \\
\text { calibrated to (A) during 1948-2008 }\end{array}$ \\
\hline $\begin{array}{l}\text { KBDI: Keetch-Byram Drought } \\
\text { Index }\end{array}$ & Fuel moisture & $\mathrm{C}$ & 1979-2013 & $1 / 8^{\circ}$ & $\begin{array}{l}\text { Calculated based on }(\mathrm{G}) \text { from NLDAS-2 } \\
\text { daily } T_{\max } \text { and precipitation }\end{array}$ \\
\hline $\begin{array}{l}\text { SPEI: Standardised Precipitation- } \\
\text { Evaporation Index }\end{array}$ & $\begin{array}{l}\text { Precipitation minus } \\
\text { evaporation }\end{array}$ & $\begin{array}{l}\mathrm{D} \\
\mathrm{E}\end{array}$ & $\begin{array}{l}1901-2011 \\
1979-2013\end{array}$ & $\begin{array}{l}0.5^{\circ} \text { interpolated to } 1 / 8^{\circ} \\
1 / 8^{\circ}\end{array}$ & $\begin{array}{l}\text { (D) extended through } 2013 \text { using (E), } \\
\text { calibrated to (D) during 1979-2011 }\end{array}$ \\
\hline ERC: Energy Release Component & $\begin{array}{l}\text { Energy released } \\
\text { when burning }\end{array}$ & $\mathrm{F}$ & $1979-2013$ & $0.04167^{\circ}$ & $\begin{array}{l}\text { Calculated by }(\mathrm{F}) \text {. Downscaled hourly }(\mathrm{C}) \\
\text { to PRISM resolution based on } \\
\text { methods from }(\mathrm{H})\end{array}$ \\
\hline
\end{tabular}

Legend: A: Sheffield et al. (2012) self-calibrated PDSI calculated with Penman-Monteith; B: National Climate Data Center monthly modified PDSI; C: NLDAS-2; D: Vicente-Serrano et al. (2010); E: Noah land surface model forced by meteorology from C; F: Abatzoglou (2013); G: Keetch and Byram (1968); H: Willmott and Robeson (1995).

24-month period within and before the wildfire year when climate anomalies had the strongest linear correlation with burned area according to the Pearson's correlation coefficient. Abatzoglou and Kolden (2013) also evaluated correlation between burned area records and climate during sliding seasonal climate windows. We conducted the correlation analyses for three SW regions: all SW, forest only and non-forest only. As in Williams et al. (2013), we calculated records of climate anomalies for forest and non-forest based on approximate species distributions of Douglas-fir (Pseudotsuga menziesii Beissn.), ponderosa pine (Pinus ponderosa Engelm.) and piñon pine (P. edulis Engelm.) (Little 1971), which approximate the distribution of SW forests. As a supplemental exercise enabling comparison to results from Abatzoglou and Kolden (2013) we repeated correlation analyses using two alternative approaches in which autocorrelation was not removed from burned area and climate records. In the first, we evaluated the non-parametric Spearman rank correlation (e.g. Skinner et al. 1999), where $\log _{10}$ burned area and climate time series were converted to ranks before correlation analysis. In the second, Pearson's correlation was evaluated using unadjusted $\log _{10}$ burned area and climate records.

\section{Model climate projections}

We utilised monthly projections of precipitation and VPD made for the fifth phase of the Coupled Model Intercomparison Project (CMIP5) and assessed for the Intergovernmental Panel on Climate Change (IPCC) Assessment Report Five. We calculated modelled VPD using methods described in Supplementary Material S3. Modelled climate data were developed for the IPCC historical experiment through 2005 and the emissions scenarios RCP 4.5 and 8.5 for 2006-2100. RCP 4.5 and RCP 8.5 are emissions scenarios in which anthropogenic radiative forcing reaches respectively $4.5 \mathrm{~W} \mathrm{~m}^{-2}$ and $8.5 \mathrm{~W} \mathrm{~m}^{-2}$ by 2100 (Moss et al. 2010; van Vuuren et al. 2011). These scenarios represent middle- and high-range emissions trajectories, which may be thought of as bounding a range of conceivable possibilities in which greenhouse gas emissions either begin to slow in the mid-21st century (RCP 4.5) or continue increasing through 2100 (RCP 8.5). For each variable, we considered all models for which data were available for all scenarios (historical, RCP 4.5, RCP 8.5). We bilinearly interpolated modelled climate fields to a common geographic resolution of $0.25^{\circ}$ so grid cells could be extracted from the SW region without artificially weighting regionally averaged climate towards model grid cells that only partially overlap with the SW. As in Williams et al. (2013), we bias-corrected modelled historical and future projections of regionally averaged SW monthly climate by standardising each month's annual time series such that mean and standard deviation for 1961-2005 matched observations.

\section{Results}

\section{4-2013 burned area}

During 1984-2013, wildfire burned more than $46200 \mathrm{~km}^{2}$ in the $\mathrm{SW}$, and $16476 \mathrm{~km}^{2}$ burned moderately or severely (see map in Fig. 1 $a$; these burned area totals do not include re-burns). Within forest, $14151 \mathrm{~km}^{2}$ (10.9\%) burned, and $8181 \mathrm{~km}^{2}$ (6.3\%) burned moderately or severely. Annual moderately and severely burned area increased at a rate of $10.2 \%$ per year $(10.2=$ $100\left[10^{0.0422}-1\right]$, where 0.0422 is the linear slope of the time series in Fig. 1b). This rate was higher for SW forest area (16.5\% per year), with a $>50 \%$ increase in post- 1984 forest area burned since 2006 (Fig. 1c). Increased forest fire area is due to increased average forest fire size and frequency (Fig. S5). Among burned forest areas, the increase was most pronounced ( $22.4 \%$ per year) in the highest third of elevations and somewhat slower $(\sim 14 \%$ per year) in the lower two elevation terciles (Fig. S6). The above trends in burned area are significant with $99.9 \%$ confidence based upon the Kendal's Tau and Spearman's Rho tests. Burned area in non-forest also increased, but the trend was not significant with 95\% confidence (Fig. 1d).

\section{Climate v. total SW annual burned area}

Annual SW burned area correlates strongly with general drought conditions during spring and summer. Correlation is strongest $(|r|=0.76-0.78)$ with spring-summer water deficit, precipitation, RH, PET and ERC (Table 2). Correlations with the supply (precipitation) and demand (PET) components of the water balance are approximately equal in strength. Among the three 
major components of spring-summer PET (insolation, VPD, wind speed), correlations with insolation and VPD are comparable $(r=0.72$ and 0.73$)$ and higher than correlation with wind speed. These correlation patterns are consistent with results derived from a Spearman rank correlation analysis (Table S1).

\section{Climate v. SW forest annual burned area}

Given the strong positive trend in burned forest area in recent decades (Fig. 1c) and possible connections to climate change (e.g. Williams et al. 2013), we focus most on area burned exclusively within SW forests (Fig. 1c). Among the 15 climate variables evaluated, correlation is strongest with March-August VPD and climatic water deficit $(r=0.74$, Fig. $2 a)$. Correlation is weaker with precipitation, but also strongest during MarchAugust ( $r=-0.63$, Fig. $2 b$ ). There is not $>95 \%$ confidence that these two correlation coefficients come from statistically distinct distributions (Snedecor and Cochran 1989), but statistical independence is not expected since precipitation is related to VPD and water deficit. Correlations with $\mathrm{T}_{\max }$ and $e_{s}$ are also optimal during late spring and summer, but slightly weaker (Fig. $2 c, d$ ). Correlation with the humidity component of VPD, $e$, is also optimised in spring-summer and weaker still (Fig. 2e). RH, which incorporates both $e$ and $e_{s}$ (as $e / e_{s}$ ) and is commonly used in evaluations of wildfire risk (e.g. Cohen and Deeming 1985), correlates strongest during April-August $(r=-0.65$, Fig. $2 f$ ).

Equal correlations for VPD and climatic water deficit suggest that forest fire area is particularly sensitive to moisture demand (i.e. PET). Correlations with NLDAS-2 PET are consistently strong and reach 0.72 during March-August (Fig. $2 g, h$ ). Among the three major contributors to March-August PET, VPD correlates stronger than March-August insolation $(r=0.57)$ and wind speed $(r=0.38)$. As was the case when considering all SW burned area (Table 2), correlation with wind speed peaks during the cold season (January-March, $r=0.53$, Fig. $2 j$ ). Relatively strong correlation with VPD appears partially due to the climate product used, as correlation is slightly lower (March-August, $r=0.68$ ) when calculated from NLDAS-2.

PET-related variables correlate relatively strongly with burned area because of PET's negative influence on fuel moisture (Flannigan and Wotton 2001; Kunkel 2001; Nelson 2001). Modelled $0-10-\mathrm{cm}$ soil moisture correlates strongest during March-August ( $r=-0.72$; Fig. $2 k$ ). Modelling soil moisture is difficult, however, and simplified drought indices are often used as proxies for fuel moisture and wildfire risk. Among the four drought indices evaluated, the KBDI correlated strongest with burned forest area (June-August, $r=0.72$; Fig. $2 l$ ). Optimal correlations for PDSI, SPEI and ERC are lower (Fig. $2 m-o$ ).

Given the relative simplicity of calculating VPD and its consistently strong correlation with burned forest area, we evaluated this relationship in more detail. Fig. $3 a$ shows that the significant positive relationship between burned area and VPD begins in autumn of the year before the wildfire year and continues throughout the wildfire season. The strong positive correlation with current-year VPD is most prominent within middle-elevation forests (Fig. 3b). Within this range (2029$2431 \mathrm{~m}$ ), correlation with VPD reaches 0.79 in spring-summer, but never exceeds 0.65 for low- and high-elevation ranges. A negative relationship exists with prior-winter-spring VPD (Fig. $3 a$ ), consistent with the well-known positive influence of reduced prior-year drought conditions on fuel growth and subsequent wildfire (e.g. Swetnam and Betancourt 1998), although the negative relationship with prior-year VPD is not significant within any of the three elevation classes considered (Fig. 3b).

Table 2. Correlation between burned area and climate

Pearson's correlation between $\log _{10}$ annual SW burned area (moderate and severe) and seasonal climate during the period of 3-6 consecutive months when correlation is optimised. First-order autocorrelation has been removed from climate and burned area records. All 3-6 month periods were considered within the 24-month window that begins in January of the prior year and ends in December of the current year. Subscript ' $p$ ' following a month indicates the prior year. VPD: vapour pressure deficit, $T_{\max }$ : maximum daily temperature, $e_{s}$ : saturation vapour pressure, $e$ : vapour pressure, RH: relative humidity, PET: potential evapotranspiration, PDSI: Palmer Drought Severity Index, KBDI: Keetch-Byram Drought Index, SPEI: Standardised Precipitation-Evaporation Index, ERC: Energy Release Component

\begin{tabular}{|c|c|c|c|c|c|c|}
\hline \multirow[t]{2}{*}{ Variable } & \multicolumn{2}{|c|}{ All SW } & \multicolumn{2}{|c|}{ Forest } & \multicolumn{2}{|c|}{ Non-forest } \\
\hline & Months & $r$ & Months & $r$ & Months & $r$ \\
\hline VPD & Mar-Aug & 0.73 & Mar-Aug & 0.74 & Jun-Aug & 0.58 \\
\hline $\log _{10}$ (precipitation) & Mar-Jul & -0.78 & Mar-Aug & -0.63 & $\operatorname{Jan}_{\mathrm{p}}-\mathrm{May}_{\mathrm{p}}$ & 0.70 \\
\hline $\mathrm{T}_{\max }$ & Jun-Aug & 0.63 & Jun-Aug & 0.63 & Jun-Aug & 0.54 \\
\hline$e_{s}$ & Jun-Aug & 0.65 & Mar-Aug & 0.64 & Jun-Aug & 0.59 \\
\hline$e$ & Mar-Aug & -0.71 & Mar-Aug & -0.50 & Mar-Jul & -0.62 \\
\hline $\mathrm{RH}$ & Apr-Sep & -0.77 & Apr-Aug & -0.65 & $\operatorname{Jan}_{\mathrm{p}}-\mathrm{May}_{\mathrm{p}}$ & 0.63 \\
\hline PET & Apr-Jul & 0.76 & Mar-Aug & 0.72 & Apr-Aug & 0.63 \\
\hline Water deficit & Mar-Aug & 0.78 & Mar-Aug & 0.74 & Apr-Aug & 0.64 \\
\hline Insolation & Mar-Jul & 0.72 & Apr-Aug & 0.57 & Mar-Jul & 0.58 \\
\hline Wind speed & Jan-Apr & 0.66 & Jan-Mar & 0.53 & Jan-Apr & 0.71 \\
\hline Soil moisture & Mar-Aug & -0.75 & Mar-Aug & -0.72 & $\operatorname{Mar}_{\mathrm{p}}-\mathrm{May}_{\mathrm{p}}$ & 0.63 \\
\hline KBDI & Jun-Sep & 0.70 & Jun-Aug & 0.72 & May-Oct & 0.60 \\
\hline PDSI & Jun-Aug & -0.67 & Jun-Aug & -0.57 & Jun-Nov & -0.64 \\
\hline SPEI & Mar-Aug & -0.63 & Mar-Aug & -0.60 & $\operatorname{Jan}_{\mathrm{p}}-\mathrm{May}_{\mathrm{p}}$ & 0.62 \\
\hline ERC & Apr-Sep & 0.76 & Mar-Aug & 0.66 & $\mathrm{Feb}_{\mathrm{p}}-\mathrm{May}_{\mathrm{p}}$ & -0.64 \\
\hline
\end{tabular}




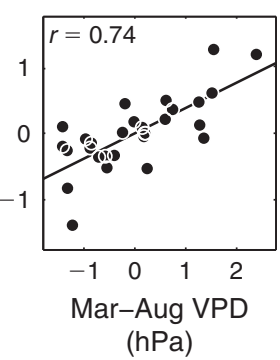

(d)

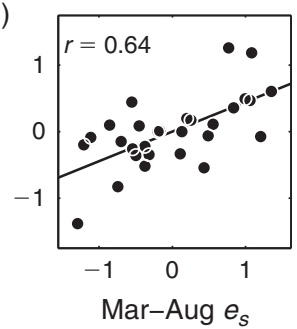

(hPa)

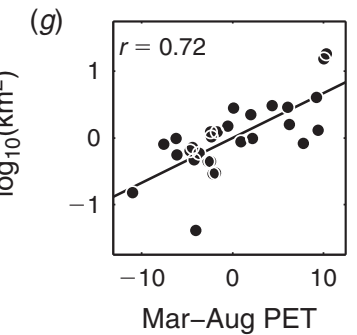

(cm)

(j)

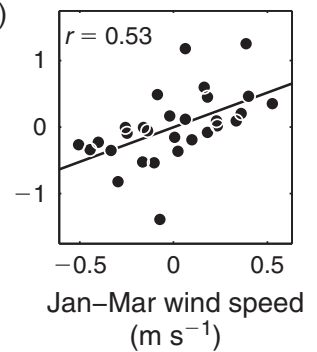

(m)

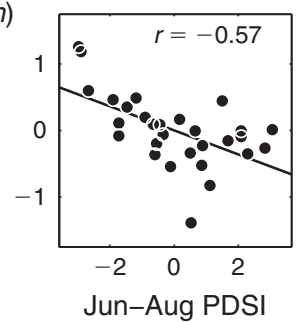

(b)

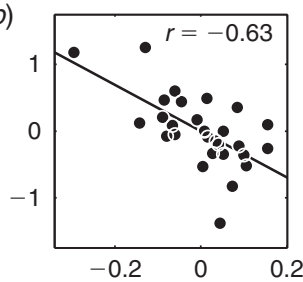

Mar-Aug precip.

$\left(\log _{10}(\mathrm{~mm})\right)$

(e)

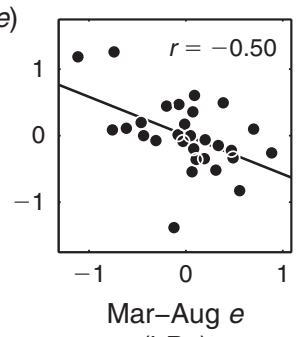

(hPa)

(h)

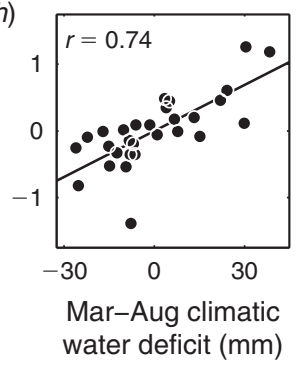

(k)

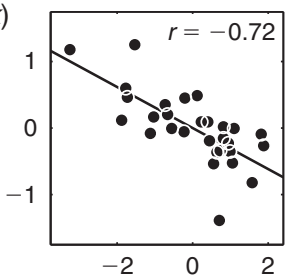

Mar-Aug 0-10 cm soil moisture $\left(\mathrm{kg} \mathrm{m}^{-2}\right)$

(n)

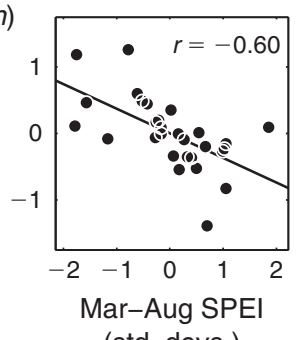

(c)

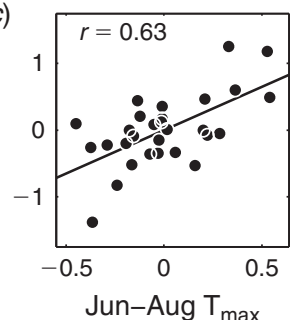

$\left({ }^{\circ} \mathrm{C}\right)$

(f)

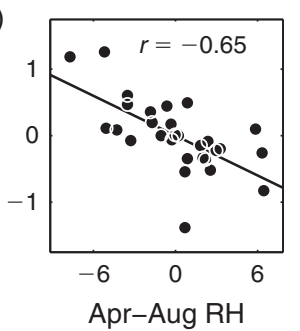

(\%)

(i)

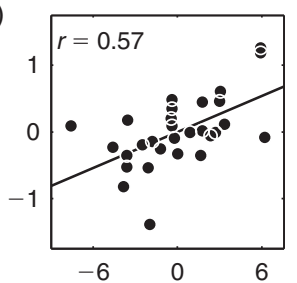

Apr-Aug insolation $\left(\mathrm{W} \mathrm{m}^{-2}\right.$ )

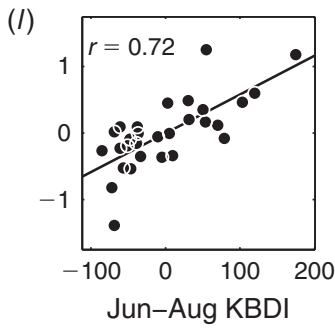

(o)

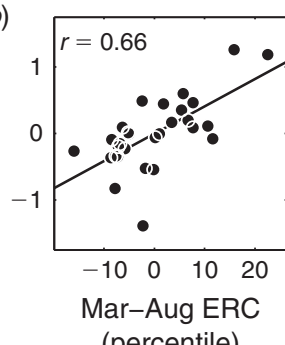

(std. devs.)

Fig. 2. Scatter plots of annual $\log _{10}$ forest burned area anomalies $(y$-axis) $v$. anomalies of 15 droughtrelated variables. The period represented by each drought variable is the range of 3-6 consecutive months when that variable correlates most strongly with annual forest burned area. First-order autocorrelation was removed from all burned area and climate time series before correlation analysis. VPD: vapour pressure deficit, $\mathrm{T}_{\mathrm{max}}$ : maximum daily temperature, $e_{s}$ : saturation vapour pressure, $e$ vapour pressure, PET: potential evapotranspiration, PDSI: Palmer Drought Severity Index, KBDI: Keetch-Byram Drought Index, SPEI: Standardised Precipitation-Evaporation Index, ERC: Energy Release Component. 


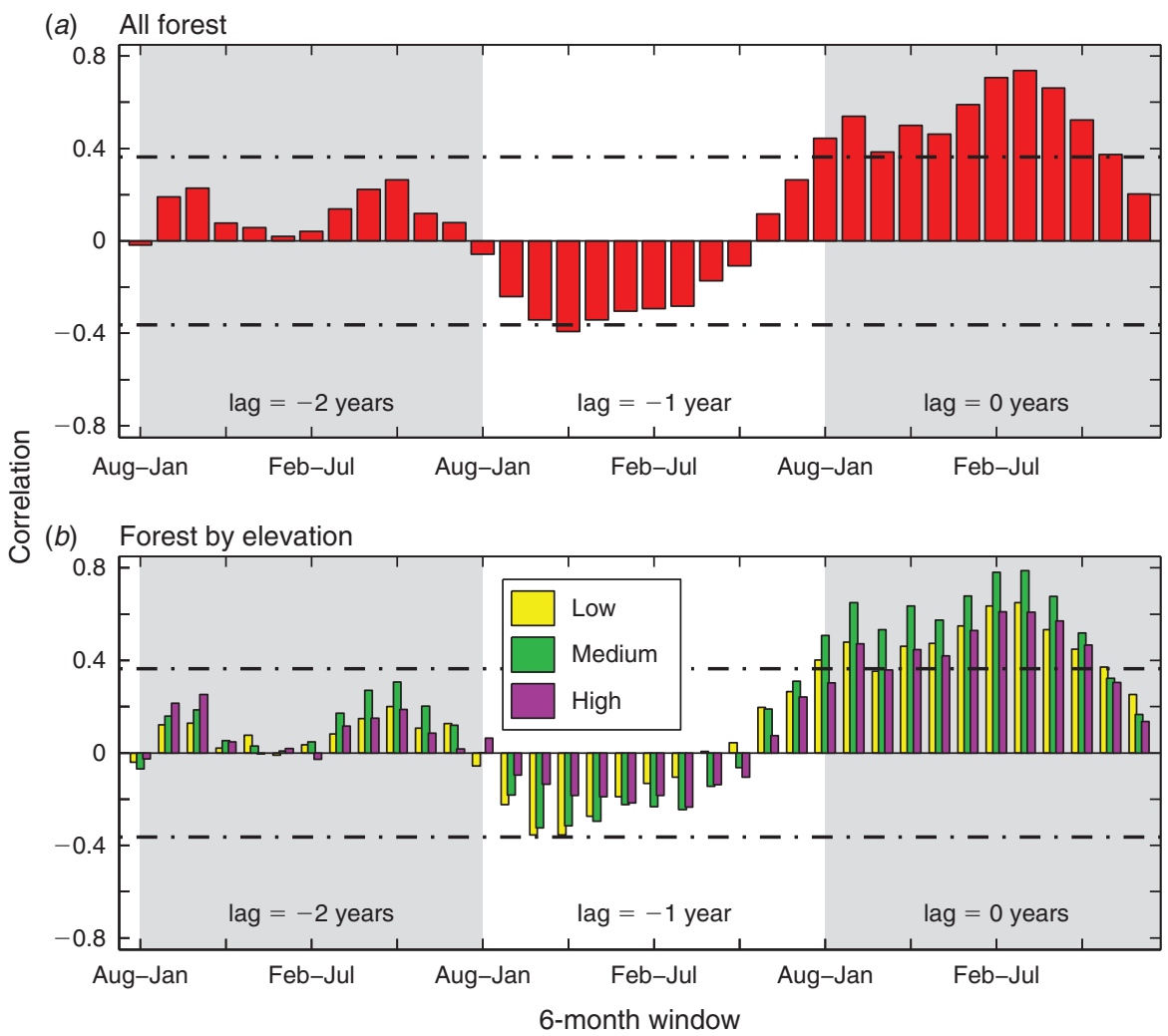

Fig. 3. Lag relationships between 6-month mean vapour pressure deficit (VPD) and annual burned forest areas $(a)$ and within three forest elevation bands $(b)$. First-order autocorrelation was removed from VPD and burned area time series before correlation analysis. Elevation bands represent the lower third, middle third and upper third of forested elevations burned during 1984-2013 (Low: 1223-2028 m, Medium: 2029-2431 m, High: 2432-3656 m). Horizontal dotted lines indicate significant correlations at the $95 \%$ confidence level $(r=0.364)$.

The results described above are essentially identical if only the MTBS data are considered and the 2013 MODIS data are excluded. The general correlation patterns are also consistent for the supplementary analysis of Spearman rank correlation (Table S1). These correlation patterns were also generally replicated in the second alternative analysis (Table S2), in which time series were considered in their original forms (unadjusted for autocorrelation or rank), as in Abatzoglou and Kolden (2013). Correlation with VPD was strongest in both alternative analyses.

\section{Climate v. non-forest annual burned area}

Unlike forest burned area, non-forest burned area correlates most strongly with winter-spring wind speed (January-April, $r=0.71)$ and prior-year precipitation during winter and spring (prior January-prior May, $r=0.70$ ) (Table 2). PET and climatic water deficit correlate optimally during spring and summer, but not as strongly. The three primary contributors to PET variability (spring-summer VPD, wind speed, insolation) correlate with non-forest burned area similarly $(r \approx 0.55)$. Optimal correlation with VPD occurs during June-August $(r=0.58)$. During this time, the temperature component of VPD $\left(e_{s}\right)$ correlates more strongly than does the humidity component $(e)$ $(r=0.59 v .-0.32)$
Climate v. annual burned area: influence of antecedent moisture conditions

Fig. 4 shows the well-documented positive influence of prioryear moisture on burned area, caused by increased fuel availability (e.g. Swetnam and Betancourt 1998; Westerling et al. 2003; Littell et al. 2009). The strength of the positive relationship with prior-year precipitation is strongest within low and mid-elevation forests, and does not reach significance in highelevation forests (Fig. 4b). The positive lag relationship is more prominent for non-forest, which is generally at lower elevation (Fig. 4c). In non-forest, burned area correlates most positively with prior-water-year precipitation during winter and spring (Table 2, Fig. 4c). In forest, correlation with prior-water-year precipitation comes earlier, peaking two months earlier for all elevation ranges (Fig. $4 a, b$ ).

\section{Implications for the future}

Fig. 5 shows CMIP5 ensemble model projections of MarchAugust VPD and February-July precipitation distributions for two 45-year periods: 2031-2075 and 1961-2005. Ensemble median March-August VPD during 2031-2075 is projected to be $12.9 \%$ (inner quartiles (iq): $7.0-15.4 \%$ ) and $16.1 \%$ (iq: 11.1 $20.1 \%$ ) higher than the baseline for the RCP 4.5 and RCP 8.5 

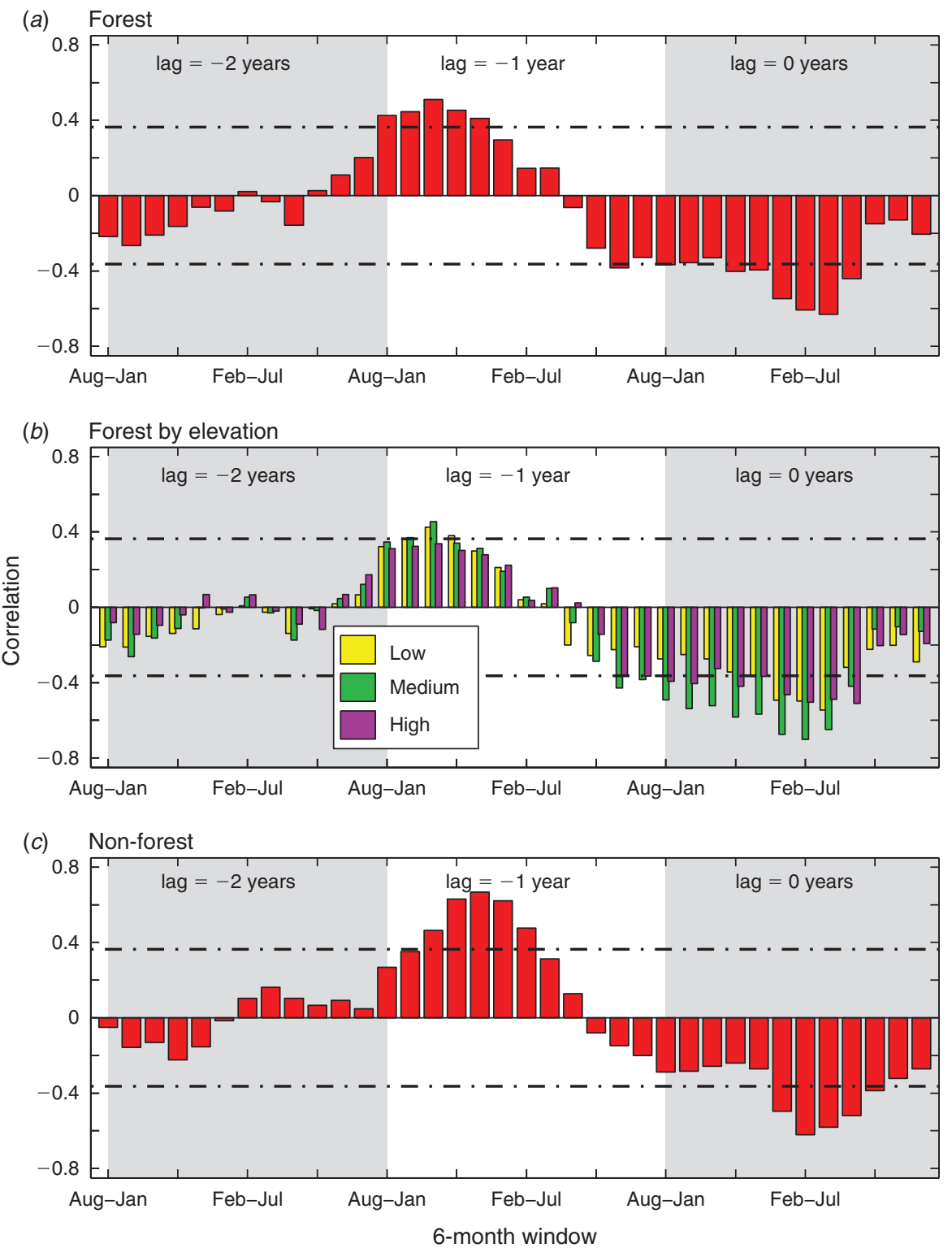

Fig. 4. Lag relationships between 6-month $\log _{10}$ precipitation totals and annual burned forest area $(a)$, burned forest areas within three elevation bands $(b)$ and burned non-forest areas. First-order autocorrelation was removed from precipitation and burned area time series before correlation analysis. Elevation bands in $(b)$ represent the lower third, middle third and upper third (as per Fig. 3) of forested elevations burned during 1984-2013. Horizontal dotted lines indicate significant correlations at the $95 \%$ confidence level $(r=0.364)$.

scenarios. Projected increases in March-August VPD are due to ensemble-mean warming of $2.15^{\circ} \mathrm{C}$ and $3.00^{\circ} \mathrm{C}$ for RCP 4.5 and RCP 8.5. Notably, atmospheric moisture content is also projected to rise in accordance with general increases in global temperatures, but the ameliorating influence of increased $e$ on VPD is small relative to the exponential influence of warming on $e_{s}$. Notably, however, extreme $e$ can still influence VPD in individual years; as in 2011, a record-breaking VPD and wildfire year (Williams et al. in press).

Three extreme SW wildfire years since 1984 were 2002, 2011 and 2012, when mean March-August VPD (18.54 hPa) was $20.4 \%$ higher than the 1961-2005 mean. The pink area in Fig. $5 a$ indicates VPD levels exceeding $18.54 \mathrm{hPa}$. Although observed and modelled records of historic March-August VPD during 1961-2005 never exceed this extreme value, models project this level to be exceeded in 15\% (iq: 5-31\%) and 38\% (iq: $12-52 \%$ ) of years during 2031-2075 in the RCP 4.5 and RCP 8.5 scenarios (Fig. 5c). Additionally, models project interannual variability of VPD to increase considerably, leading to an increased frequency of extreme excursions of VPD from the positive background trend in mean VPD (Williams et al. in press). 
(a)

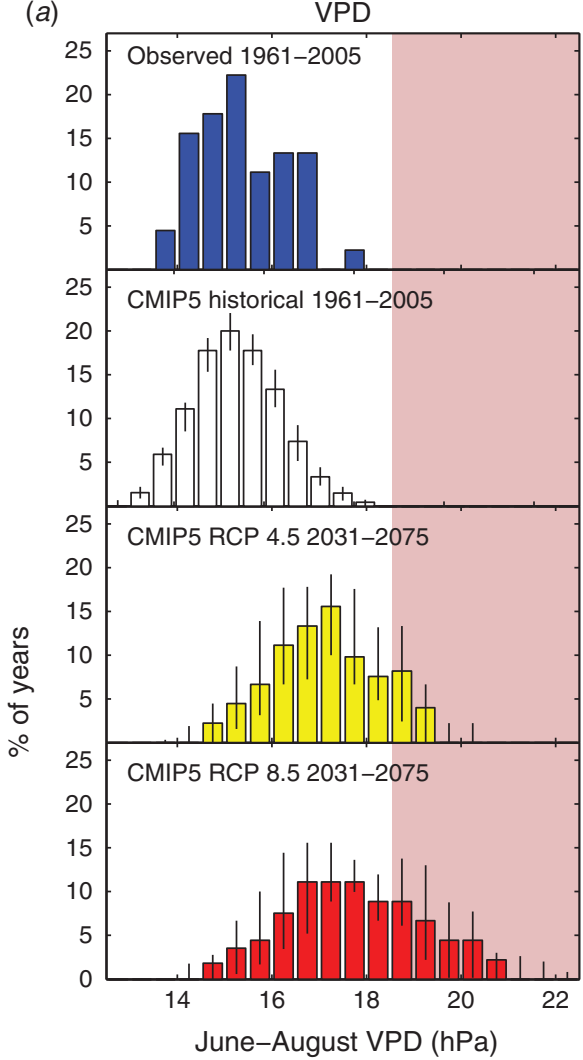

(c)

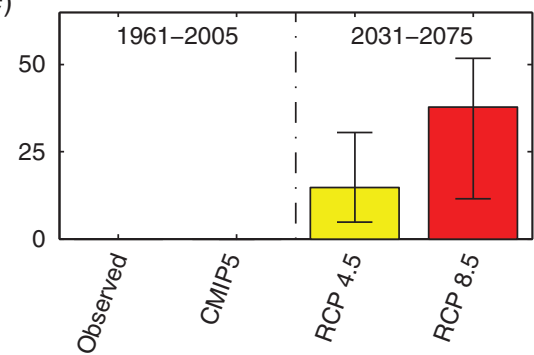

(b)

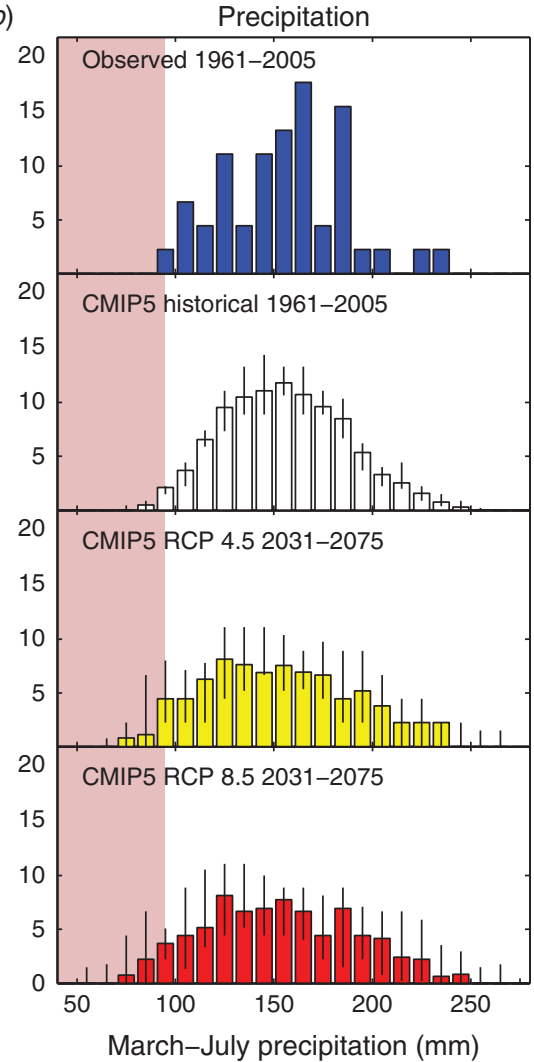

(d)

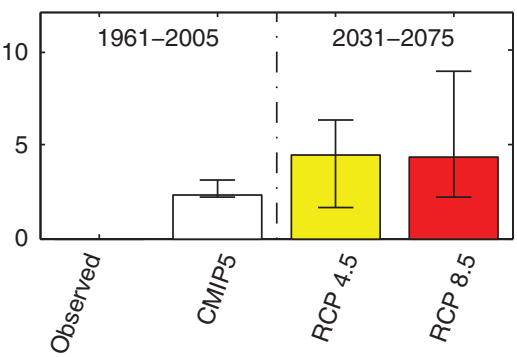

Fig. 5. Observed and model projected vapour pressure deficit (VPD) and precipitation in the SW for two 45-year periods: 1961-2005 and 2031-2075. Panels ( $a$ and $b$ ) show histograms of March-August VPD (a) and March-July precipitation (b). In $(a$ and $b)$, the shaded area represents conditions more extreme than the average of 2002, 2011 and 2012, the three years with the highest March-August VPD on record. Panels $(c$ and $d$ ) show the percentage of years when conditions exceed extreme levels for $\operatorname{VPD}(c)$ and precipitation $(d)$. All bars representing model projections indicate the model ensemble-median value. Whiskers indicate model ensemble inner quartiles. For VPD, $n=23$ models. For precipitation, $n=26$ models.

The right side of Fig. 5 examines CMIP5 projections of precipitation during March-July, the period when precipitation correlates most strongly with SW burned area (Table 2). CMIP5 models do not converge upon a projected change in mean precipitation during these months (though they do converge on less cold season precipitation) but they do project a shift towards increased frequencies of abnormally wet and dry years (Fig. 5b), with an approximately doubled probability of MarchJuly precipitation in a given year from 2031-2075 being less than the mean of 2002, 2011 and 2012 (Fig. 5d).

\section{Discussion and conclusions}

Previous investigations identified mean seasonal temperature as an important driver of annual wildfire in the western United States (e.g. Westerling et al. 2006; Littell et al. 2009), but did not explore wildfire relationships with VPD, which is the more direct link between temperature and water balance (but see Sedano and Randerson 2014). Moisture content of fine fuels such as dead grass and needles equilibrates with atmospheric VPD within hours and moisture content of larger fuels like dead logs equilibrates over weeks to months (Simard 1968; Fosberg 
and Furman 1973; Viney 1991; Nelson 2001). VPD also influences soil moisture on sub-seasonal to multi-year timescales, influencing flammability of live vegetation (Nelson 2001). Williams et al. (2013) explored VPD, but that study linked VPD to regional forest drought stress, and forest drought stress to burned area, without exploring VPD-wildfire relationships directly. In a comprehensive analysis of relationships between climate and western United States forest fire area, Abatzoglou and Kolden (2013) did not consider VPD explicitly, but did find optimal relationships with PET, which is mainly driven by VPD, solar insolation and wind speed.

It is interesting that we find correlation with VPD to be at least as strong as correlation with more comprehensive calculations of moisture demand or the full water balance, which all include VPD in their calculations. We interpret the unexpectedly strong correlation with VPD to indicate that correlation between burned area and other more comprehensive drought metrics may be artificially suppressed due to uncertainties in climate records as well as some confounding effects. This has important implications for evaluation of wildfire vulnerability in SW forests and elsewhere.

One confounding issue that may suppress burned area correlations with other drought indicators is that warm season precipitation often co-occurs with lightning-induced ignition events, inherently dampening the negative correlation between moisture supply and burned area (e.g. Price and Rind 1994). Co-occurrence of clouds (which reduce insolation) and lightning (which provides ignitions) may also suppress correlations between burned area and insolation, thereby suppressing correlation with PET and modelled moisture balance. Also, complex topography and land cover characteristics cause difficulty in modelling processes such as snowmelt and sublimation, runoff, evaporation from the canopy and microclimate (e.g. Byram and Jemison 1943), which dictate how precipitation translates to fuel moisture. This is exemplified by substantial differences in modelled SW moisture budget among land surface models despite identical meteorological forcing (Fig. S7).

Additionally, the positive influence of precipitation on vegetation growth, and thus fuel abundance, works against the negative correlation between current-year precipitation and burned area, ultimately suppressing correlation between water balance and burned area. We find a similarly positive correlation with prior-year precipitation among the three forest elevation classes we evaluated, contrary to what might be expected based on the multi-century fire scar analysis by Swetnam and Betancourt (1998), which found that prior-year wet conditions only enhanced the probability of widespread wildfire in relatively open SW forests, which are more common at lower elevations. We hypothesise that wildfire effects on SW forests have become less elevation dependent in recent decades as forest fires have grown increasingly large and expansive across elevations (Fig. S8). Increased frequency of large fires spanning elevation classes may cause high elevation forest to become increasingly susceptible to fire spread from lower elevations.

Confounding effects also suppress positive correlation between burned area and wind speed, which is important in driving wildfire spread (e.g. Taylor et al. 2004; Linn et al. 2012) and evapotranspiration (Monteith 1965). First, quality of wind speed data is suboptimal within montane forests because wind speed data largely represent conditions in relatively open settings with low surface roughness, but the greater surface roughness and complex structure of forests at least partially decouples wind speeds within the forest canopy from those outside the canopy (Belcher et al. 2012). This undoubtedly causes regional simulations of wind speed to poorly represent the influence of wind on PET within a forest, which is a point worthy of consideration in calculations of global drought (e.g. Sheffield et al. 2012). Second, correlation with wind speed may be suppressed during the warm season because wind-driven surface cooling during high solar intensities may counteract the drying effect of wind by decreasing boundary layer humidity (Byram and Jemison 1943). Finally, evaporation may be particularly sensitive to wind speed when fuel moisture is high, but less so at lower moistures (e.g. Van Wagner 1979). These last two points may contribute to the tendency for burned area to correlate most strongly with wind speed during winter and early spring, and may also contribute to suppressed correlations with PET.

In contrast to the confounding effects described above, relatively strong correlation with VPD is likely due to (1) fewer opposing interactions between VPD and burned area; (2) enhanced accuracy of PRISM VPD, particularly due to PRISM's inclusion of data from many SW sites within the RAWS network; and (3) the fact that VPD not only influences moisture demand, but also responds to moisture supply. VPD inherently reflects information about surface moisture supply because surface moisture strongly influences near-surface humidity and daytime temperature via evapotranspiration. For example, April-June mean $\mathrm{T}_{\max }$, dew point and VPD correlate significantly with antecedent (October-March) precipitation in SW forest regions (Fig. S9). Future work should explore the utility of VPD as a comprehensive integrator of regional moisture availability, which may complement model-based estimates of regional fuel moisture and wildfire risk.

In the near term, we expect burned SW forest area to continue co-varying with climate in a nature similar to that established in recent decades. Over the longer term, drought intensification is very likely in the SW (e.g. Cayan et al. 2013; Gershunov et al. 2013; Seager et al. 2013; Williams et al. 2013), but forest fire response will be complicated because many factors influence regional fuel characteristics (e.g. Nelson 2001; Moritz et al. 2012; Pfeiffer et al. 2013). Based simply on an extrapolation of the established relationship between forest fire area and VDP (Fig. 6), continued warming would result in ever-growing annual burned area. Continued increases in burned area, however, would eventually cause a negative feedback on future burned area via reductions in fuel availability and connectivity (Schoennagel et al. 2004; Krawchuk et al. 2009; Pechony and Shindell 2010; Marlon et al. 2012).

Management policies will also modulate the future relationships between burned area and drought. Recent increases in SW burned area, for example, are partially attributable to increased forest density due to regional fire suppression (Fulé et al. 1997; Allen et al. 2002; Stephens 2005; Marlon et al. 2012; but also see Schoennagel et al. 2004). Additionally, nuances of the climate system such as sequencing of wet and dry years, and co-occurrence of drought, ignition and wind events, will continue to be important. For these reasons, fully mechanistic land 


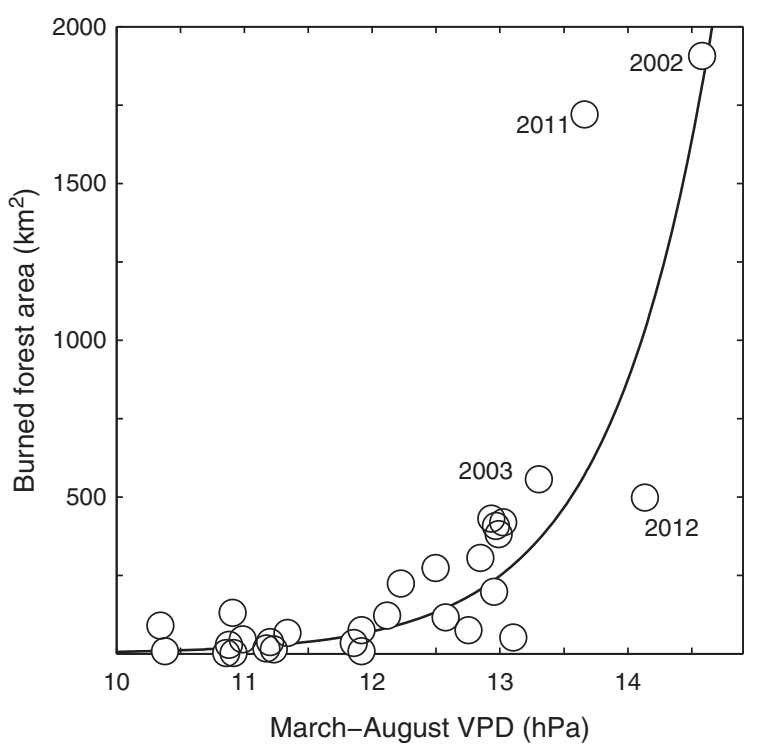

Fig. 6. Annual burned forest area $v$. mean March-August vapour pressure deficit (VPD) in forest during 1894-2013. As in Fig. 2a, but values are not adjusted for autocorrelation and $y$-axis is not on a log scale. The four largest burned area years are labelled.

surface models will be of increasing value as wildfire parameterisations continue to improve (e.g. Kloster et al. 2010; Pfeiffer et al. 2013). However, fuel moisture is ultimately affected by micrometeorology (Byram and Jemison 1943; Nelson 2001) and it is not necessarily clear how regional climate change will translate to trends in boundary layer conditions surrounding fuels. Trends in micrometeorology and boundary layer climate will be spatially heterogeneous and heavily influenced by changes in vegetation cover. In turn, regionally averaged trends in burned area will be an integration of many site-specific processes, many of which are not accurately represented in global climate models.

Despite uncertainties, rapidly rising VPD and continued occurrences of abnormally wet years (fuel growth) followed by abnormally dry years (fuel drying) are likely to continue to increase flammability of SW ecosystems until fuels or management policies become limiting. In forested areas globally, changing fire dynamics may lead to critical feedbacks on global and regional climates, as forests store $\sim 45 \%$ of terrestrial carbon and substantially influence regional water cycles (Bonan 2008; Le Page et al. 2010; Chen et al. 2011; Jasechko et al. 2013; Gatti et al. 2014). Observed wildfire-climate relationships in relatively warm and dry forests of the SW offer valuable insights relevant to other forest regions globally, particularly in regions where VPD is projected to rise rapidly, regions that experienced recent pluvial conditions that suppressed burned area and promoted fuel growth, and regions where limited meteorological and land cover data prohibit accurate fuel moisture modelling.

\section{Acknowledgements}

This work was supported by LANL-LDRD and DoE-BER. RS was supported by NOAA awards NA10OAR4310137 (Global Decadal Hydroclimate Variability and Change) and NSF award EASM2: Linking Near-term Future Changes in Weather and Hydroclimate in Western North
America to Adaptation for Ecosystem and Water Management. Thanks to J. T. Abatzoglou, C. D. Allen, C. Baisan, B. I. Cook, E. R. Cook, C. Daly, E. H.(T.) Hogg, B. E. Law, R. R. Linn, N. Pederson, S. A. Rauscher, J. Sheffield, and A. M. Strong for insightful conversations.

\section{References}

Abatzoglou JT (2013) Development of gridded surface meteorological data for ecological applications and modelling. International Journal of Climatology 33, 121-131. doi:10.1002/JOC.3413

Abatzoglou JT, Kolden CA (2013) Relationships between climate and macroscale area burned in the western United States. International Journal of Wildland Fire 22, 1003-1020. doi:10.1071/WF13019

Adams HD, Guardiola-Claramonte M, Barron-Gafford GA, Villegas JC, Breshears DD, Zou CB, Troch PA, Huxman TE (2009) Temperature sensitivity of drought-induced tree mortality portends increased regional die-off under global change-type drought. Proceedings of the National Academy of Sciences of the United States of America 106, 7063-7066. doi:10.1073/PNAS.0901438106

Allen CD, Savage M, Falk DA, Suckling KF, Swetnam TW, Schulke T, Stacey PB, Morgan P, Hoffman M, Klingel JT (2002) Ecological restoration of southwestern ponderosa pine ecosystems: a broad perspective. Ecological Applications 12, 1418-1433. doi:10.1890/1051 0761(2002)012[1418:EROSPP]2.0.CO;2

Anderson DB (1936) Relative humidity or vapor pressure deficit. Ecology 17, 277-282. doi:10.2307/1931468

Belcher SE, Harman IN, Finnigan JJ (2012) The wind in the willows: flows in forest canopies in complex terrain. Annual Review of Fluid Mechanics 44, 479-504. doi:10.1146/ANNUREV-FLUID-120710-101036

Benson RP, Roads JO, Weise DR (2009) Climatic and weather factors affecting fire occurrence and behavior. In 'Wildland Fires and Air Polution: Developments in Environmental Science'. (Eds A Bytnerowicz, M Arbaugh, C Andersen, A Riebau) pp. 37-60. (Elsevier: The Netherlands)

Bonan GB (2008) Forests and climate change: forcings, feedbacks, and climate benefits of forests. Science 320, 1444-1449. doi:10.1126/ SCIENCE. 1155121

Byram GM, Jemison GM (1943) Solar radiation and forest fuel moisture. Journal of Agricultural Research 67, 149-176.

Cayan D, Tyree M, Kunkel KE, Castro C, Gershunov A, Barsugli J, Ray AJ, Overpeck J, Anderson M, Russell B, Rajogopalan B, Rangwala I, Duffy P (2013) Future climate: projected average. In 'Assessment of Climate Change in the Southwest United States: a Report Prepared for the National Climate Assessment'. (Eds G Garfin, A Jardine, R Merideth, M Black, S LeRoy) pp. 101-125. (Island Press: Washington, DC)

Chen Y, Randerson JT, Morton DC, DeFries RS, Collatz GJ, Kasibhatla PS, Giglio L, Jin Y, Marlier ME (2011) Forecasting fire season severity in South America using sea surface temperature anomalies. Science 334, 787-791. doi:10.1126/SCIENCE. 1209472

Cohen JD, Deeming JE (1985) The national fire-danger rating system: basic equations. USDA Forest Service, Pacific Southwest Forest and Range Experiment Station, Report PSW-12. (Berkeley, CA) Available at http:// www.treesearch.fs.fed.us/pubs/27298/ [Verified 9 October 2014]

Crimmins MA, Comrie AC (2004) Interactions between antecedent climate and wildfire variability across south-eastern Arizona. International Journal of Wildland Fire 13, 455-466. doi:10.1071/WF03064

Daly C, Gibson WP, Dogget M, Smith J, Taylor G (2004) Up-to-date monthly climate maps for the coterminous United States. In 'Proceedings of the 14th AMS Conference on Applied Climatology, 84th AMS Annual Meeting', 13-16 January 2004, Seattle, WA (American Meteorological Society: Boston, MA). Available from https://ams.confex.com/ams/pdfpapers/ 71444.pdf?origin=publication_detail [Verified 9 October 2014]

Dillon GK, Holden ZA, Morgan P, Crimmins MA, Heyerdahl EK, Luce $\mathrm{CH}$ (2011) Both topography and climate affected forest and woodland burn severity in two regions of the western US, 1984 to 2006. Ecosphere 2(12), Article 130. doi:10.1890/ES11-00271.1 
Eidenshink J, Schwind B, Brewer K, Zhu Z, Quayle B, Howard S (2007) A project for monitoring trends in burn severity. Fire Ecology 3, 3-21. doi:10.4996/FIREECOLOGY.0301003

Flannigan MD, Wotton BM (2001) Climate, weather, and area burned. In 'Forest Fires: Behavior and Ecological Effects'. (Eds EA Johnson, K Miyanishi) pp. 351-369. (Academic Press: San Diego, CA)

Fleishman E, Belnap J, Enquist AFE, Ford K, MacDonald GM, Pellant M, Schoennagel T, Schmit LM, Schwartz M, van Drunick S, Westerling AL, Keyser A, Lucas R (2013) Natural Ecosystems. In 'Assessment of Climate Change in the Southwest United States: a Report Prepared for the National Climate Assessment'. (Eds G Garfin, A Jardine, R Merideth, M Black, S LeRoy) pp. 148-167. (Island Press: Washington, DC)

Fosberg MA, Furman RW (1973) Fire climates in the southwest. Agricultural Meteorology 12, 27-34. doi:10.1016/0002-1571(73)90004-6

Fujioka FM, Gill AM, Viegas DX, Wotton BM (2009) Fire danger and fire behavior modeling systems in Australia, Europe, and North America. In 'Wildland Fires and Air Pollution: Developments in Environmental Science'. (Eds A Bytnerowicz, M Arbaugh, C Andersen, A Riebau) pp. 471-497. (Elsevier: The Netherlands)

Fulé PZ, Covington WW, Moore MM (1997) Determining reference conditions for ecosystem management of southwestern ponderosa pine forests. Ecological Applications 7, 895-908. doi:10.1890/1051-0761 (1997)007[0895:DRCFEM]2.0.CO;2

Gatti LV, Gloor M, Miller JB, Doughty CE, Malhi Y, Dominguez LG, Basso LS, Martenewski A, Correia CSC, Borges VF, Freitas S, Braz R, Anderson LO, Rocha H, Grace J, Phillips OL, Lloyd J (2014) Drought sensitivity of Amazonian carbon balance revealed by atmospheric measurements. Nature 506, 76-80. doi:10.1038/NATURE12957

Gershunov A, Rajagopalan B, Overpeck J, Guirguis K, Cayan D, Hughes M, Dettinger M, Castro C, Schwartz RE, Anderson M, Ray AJ, Barsugli J, Cavazos T, Alexander M (2013) Future climate: projected extremes. In 'Assessment of Climate Change in the Southwest United States: a Report Prepared for the National Climate Assessment'. (Eds G Garfin, A Jardine, R Merideth, M Black, S LeRoy) pp. 126-147. (Island Press: Washington, DC)

Grissino Mayer HD, Swetnam TW (2000) Century scale climate forcing of fire regimes in the American Southwest. The Holocene 10, 213-220. doi:10.1191/095968300668451235

Holden ZA, Morgan P, Crimmins MA, Steinhorst RK, Smith AMS (2007) Fire season precipitation variability influences fire extent and severity in a large southwestern wilderness area, United States. Geophysical Research Letters 34, L16708. doi:10.1029/2007GL030804

Holden ZA, Morgan P, Evans JS (2009) A predictive model of burn severity based on 20-year satellite-inferred burn severity data in a large southwestern US wilderness area. Forest Ecology and Management 258, 2399-2406. doi:10.1016/J.FORECO.2009.08.017

Jasechko S, Sharp ZD, Gibson JJ, Birks J, Yi Y, Fawcett PJ (2013) Terrestrial water fluxes dominated by transpiration. Nature 496, 347-350. doi:10.1038/NATURE11983

Keetch JJ, Byram GM (1968) A drought index for forest fire control. UDSA Forest Service, Southeastern Forest Experiment Station, Report SE-38 (Asheville, NC). Available at http://www.srs.fs.usda.gov/pubs/40 [Verified 9 October 2014]

Kloster S, Mahowald NM, Randerson JT, Thornton PE, Hoffman FM, Levis S, Lawrence PJ, Feddema JJ, Oleson KW, Lawrence DM (2010) Fire dynamics during the 20th century simulated by the Community Land Model. Biogeosciences Discussions 7, 1877-1902. doi:10.5194/ BG-7-1877-2010

Krawchuk MA, Moritz MA, Parisien M-A, Van Dorn J, Hayhoe K (2009) Global pyrogeography: the current and future distribution of wildfire. PLoS ONE 4, e5102. doi:10.1371/JOURNAL.PONE.0005102

Kunkel KE (2001) Surface energy budget and fuel moisture. In 'Forest Fires: Behavior and Ecological Effects'. (Eds EA Johnson, K Miyanishi) pp. 303-350. (Academic Press: San Diego, CA)
Le Page Y, van der Werf GR, Morton DC, Pereira JMC (2010) Modeling fire-driven deforestation potential in Amazonia under current and projected climate conditions. Journal of Geophysical ResearchBiogeosciences 115, G03012. doi:10.1029/2009JG001190

Linn R, Anderson K, Winterkamp JL, Brooks A, Wotton M, Dupuy J-L, Pimont F, Edminster C (2012) Incorporating field wind data into FIRETEC simulations of the International Crown Fire Modeling Experiment (ICFME): preliminary lessons learned. Canadian Journal of Forest Research 42, 879-898. doi:10.1139/X2012-038

Linn RR, Sieg CH, Hoffman CM, Winterkamp JL, McMillin JD (2013) Modeling wind fields and fire propagation following bark beetle outbreaks in spatially-heterogeneous pinyon-juniper woodland fuel complexes. Agricultural and Forest Meteorology 173, 139-153. doi:10.1016/J.AGRFORMET.2012.11.007

Littell JS, McKenzie D, Peterson DL, Westerling AL (2009) Climate and wildfire area burned in Western US ecoprovinces, 1916-2003. Ecological Applications 19, 1003-1021. doi:10.1890/07-1183.1

Little EL, Jr (1971) 'Atlas of United States Trees; Vol. 1. Conifers and Important Hardwoods.' (USDA Forest Service: Washington, DC).

Marlon J, Bartlein P, Walsh M, Harrison S, Brown K, Edwards M, Higuera P, Power M, Anderson R, Briles C (2009) Wildfire responses to abrupt climate change in North America. Proceedings of the National Academy of Sciences of the United States of America 106, 2519-2524. doi:10.1073/PNAS.0808212106

Marlon JR, Bartlein PJ, Gavin DG, Long CJ, Anderson RS, Briles CE, Brown KJ, Colombaroli D, Hallett DJ, Power MJ (2012) Long-term perspective on wildfires in the western USA. Proceedings of the National Academy of Sciences of the United States of America 109, E535-E543. doi:10.1073/PNAS.1112839109

Mitchell KE, Lohmann D, Houser PR, Wood EF, Schaake JC, Robock A, Cosgrove BA, Sheffield J, Duan Q, Luo L, Higgins RW, Pinker RT, Tarpley JD, Lettenmaier DP, Marshall CH, Entin JK, Pan M, Shi W, Koren V, Meng J, Ramsay BH, Bailey AA (2004) The multi-institution North American Land Data Assimilation System (NLDAS): utilizing multiple GCIP products and partners in a continental distributed hydrological modeling system. Journal of Geophysical Research 109, D07S90. doi:10.1029/2003JD003823

Monteith JL (1965) Evaporation and environment. Symposia of the Society for Experimental Biology 19, 205-224.

Moritz MA, Parisien MA, Batllori E, Krawchuk MA, Van Dorn J, Ganz DJ, Hayhoe K (2012) Climate change and disruptions to global fire activity. Ecosphere 3(6), Article 49. doi:10.1890/ES11-00345.1

Moss RH, Edmonds JA, Hibbard KA, Manning MR, Rose SK, van Vuuren DP, Carter TR, Emori S, Kainuma M, Kram T (2010) The next generation of scenarios for climate change research and assessment. Nature 463, 747-756. doi:10.1038/NATURE08823

Nelson RM, Jr (2001) Water relations of forest fuels. In 'Forest Fires: Behavior and Ecological Effects'. (Eds EA Johnson, K Miyanishi) pp. 79-143. (Academic Press: San Diego, CA)

Palmer WC (1965) 'Meteorological Drought, Research Paper No. 45.' (US Department of Commerce-Weather Bureau: Washington, DC)

Pechony O, Shindell DT (2010) Driving forces of global wildfires over the past millennium and the forthcoming century. Proceedings of the National Academy of Sciences of the United States of America 107, 19 167-19 170. doi:10.1073/PNAS.1003669107

Pfeiffer M, Spessa A, Kaplan JO (2013) A model for global biomass burning in preindustrial time: LPJ-LMfire (v1.0). Geoscientific Model Development 6, 643-685. doi:10.5194/GMD-6-643-2013

Price C, Rind D (1994) The impact of a 2 X CO2 climate on lightningcaused fires. Journal of Climate 7, 1484-1494. doi:10.1175/1520-0442 (1994)007<1484:TIOACC >2.0.CO;2

Riley KL, Abatzoglou JT, Grenfell IC, Klene AE, Heinsch FA (2013) The relationship of large fire occurrence with drought and fire danger indices in the western USA, 1984-2008: the role of temporal scale. 
International Journal of Wildland Fire 22, 894-909. doi:10.1071/ WF12149

Rothermel RC (1983) 'How to Predict the Spread and Intensity of Forest and Range Fires.' (National Wildlife Coordinating Group-USDA Forest Service: Boise, Idaho).

Roy DP, Boschetti L, Justice CO, Ju J (2008) The Collection 5 MODIS Burned Area Product - global evaluation by comparison with the MODIS Active Fire Product. Remote Sensing of Environment 112 3690-3707. doi:10.1016/J.RSE.2008.05.013

Schoennagel T, Veblen TT, Romme WH (2004) The interaction of fire, fuels, and climate across Rocky Mountain forests. Bioscience 54, 661-676. doi:10.1641/0006-3568(2004)054[0661:TIOFFA]2.0.CO;2

Seager R, Ting M, Li C, Naik N, Cook B, Nakamura J, Liu H (2013) Projections of declining surface-water availability for the southwestern United States. Nature Climate Change 3, 482-486. doi:10.1038/ NCLIMATE1787

Sedano F, Randerson JT (2014) Vapor pressure deficit controls on fire ignition and fire spread in boreal forest ecosystems. Biogeosciences Discussions 11, 1309-1353. doi:10.5194/BGD-11-1309-2014

Sheffield J, Wood EF, Roderick ML (2012) Little change in global drought over the past 60 years. Nature 491, 435-438. doi:10.1038/ NATURE11575

Simard AJ (1968) The moisture content of forest fuels. Forest Fire Research Institute, Report FF-X-14 (Ottawa, ON). Available at http://nofc.cfs. nrcan.gc.ca/bookstore_pdfs/24782.pdf [Verified 9 October 2014]

Skinner W, Stocks B, Martell D, Bonsal B, Shabbar A (1999) The association between circulation anomalies in the mid-troposphere and area burned by wildland fire in Canada. Theoretical and Applied Climatology 63, 89-105. doi:10.1007/S007040050095

Snedecor GW, Cochran WG (1989) 'Statistical Methods, Eighth Edition'. (Iowa State University Press: Ames, IA)

Stephens SL (2005) Forest fire causes and extent on United States Forest Service lands. International Journal of Wildland Fire 14, 213-222. doi:10.1071/WF04006

Swetnam TW, Betancourt JL (1990) Fire-southern oscillation relations in the southwestern United States. Science 249, 1017-1020. doi:10.1126 SCIENCE.249.4972.1017

Swetnam TW, Betancourt JL (1998) Mesoscale disturbance and ecological response to decadal climatic variability in the American Southwest. Journal of Climate 11, 3128-3147. doi:10.1175/1520-0442(1998) $011<3128$ :MDAERT $>2.0 . \mathrm{CO} ; 2$

Taylor SW, Wotton BM, Alexander ME, Dalrymple GN (2004) Variation in wind and crown fire behaviour in a northern jack pine black spruce forest. Canadian Journal of Forest Research 34, 1561-1576. doi:10.1139/X04-116

Trouet V, Taylor AH, Carleton AM, Skinner CN (2006) Fire-climate interactions in forests of the American Pacific coast. Geophysical Research Letters 33, L18704. doi:10.1029/2006GL027502

van Mantgem PJ, Nesmith JCB, Keifer M, Knapp EE, Flint A, Flint L (2013) Climatic stress increases forest fire severity across the western United States. Ecology Letters 16, 1151-1156. doi:10.1111/ELE. 12151

van Vuuren DP, Edmonds J, Kainuma M, Riahi K, Thomson A, Hibbard K, Hurtt GC, Kram T, Krey V, Lamarque J-F (2011) The representative concentration pathways: an overview. Climatic Change 109, 5-31. doi:10.1007/S10584-011-0148-Z

Van Wagner CE (1979) A laboratory study of weather effects on the drying rate of jack pine litter. Canadian Journal of Forest Research 9, 267-275. doi:10.1139/X79-044

Vicente-Serrano SM, Begueria S, Lopez-Moreno JI (2010) A multiscalar drought index sensitive to global warming: the standardized precipitation evapotranspiration index. Journal of Climate 23, 1696-1718. doi:10.1175/2009JCLI2909.1

Viney NR (1991) A review of fine fuel moisture modeling. International Journal of Wildland Fire 1, 215-234. doi:10.1071/WF9910215

Werth PA, Potter BE, Clements CB, Finney MA, Goodrick SL, Alexander ME, Cruz MG, Forthofer JA, McAllister SS (2011) Synthesis of knowledge of extreme fire behavior: volume I for fire managers. USDA Forest Service, Report PNW-GTR-854. (Portland, OR) Available at http://www. met.sjsu.edu/ clements/pnw_gtr854.pdf [Verified 9 October 2014]

Westerling AL, Gershunov A, Cayan DR, Barnett TP (2002) Long lead statistical forecasts of area burned in western US wildfires by ecosystem province. International Journal of Wildland Fire 11, 257-266. doi:10.1071/WF02009

Westerling AL, Gershunov A, Brown TJ, Cayan DR, Dettinger MD (2003) Climate and wildfire in the western United States. Bulletin of the American Meteorological Society 84, 595-604. doi:10.1175/BAMS84-5-595

Westerling AL, Hidalgo HG, Cayan DR, Swetnam TW (2006) Warming and earlier spring increase western US forest wildfire activity. Science 313, 940-943. doi:10.1126/SCIENCE.1128834

Williams AP, Allen CD, Millar CI, Swetnam TW, Michaelsen J, Still CJ, Leavitt SW (2010) Forest responses to increasing aridity and warmth in the southwestern United States. Proceedings of the National Academy of Sciences of the United States of America 107, 21289 21 294. doi:10.1073/PNAS.0914211107

Williams AP, Allen CD, Macalady AK, Griffin D, Woodhouse CA, Meko DM, Swetnam TW, Rauscher SA, Seager R, Grissino Mayer HD, Dean JS, Cook ER, Gangodagamage C, Cai M, McDowell NG (2013) Temperature as a potent driver of regional forest drought stress and tree mortality. Nature Climate Change 3, 292-297. doi:10.1038/ NCLIMATE1693

Williams AP, Seager R, Berkelhammer M, Macalady AK, Crimmins MA, Swetnam TW, Trugman AT, Buenning N, Noone D, McDowell NG, Hryniw N, Mora CI, Rahn T Causes and future implications of extreme 2011 atmospheric moisture demand and wildfire in the southwest United States. Journal of Applied Meteorology and Climatology, in press. doi:10.1175/JAMC-D-14-0053.1

Willmott CJ, Robeson SM (1995) Climatologically aided interpolation (CAI) of terrestrial air temperature. International Journal of Climatology 15, 221-229. doi:10.1002/JOC.3370150207

Xia Y, Mitchell K, Ek MB, Sheffield J, Cosgrove BA, Wood E, Luo L, Alonge C, Wei H, Meng J, Linvneh B, Lettenmaier DP, Koren V, Duan Q, Mo K, Fan Y, Mocko D (2012) Continental-scale water and energy flux analysis and validation for the North American Land Data Assimilation System project phase 2 (NLDAS-2): 1. Intercomparison and application of model products. Journal of Geophysical Research 117, D03109. 